\title{
Calciotrophic hormones during experimental hypocalcaemia and hypercalcaemia in spontaneously diabetic rats
}

\author{
J Verhaeghe ${ }^{1,2}$, R van Bree ${ }^{1}$, E Van Herck², I Jans², Z Zaman ${ }^{3}$ \\ and $\mathbf{R}$ Bouillon ${ }^{2}$ \\ ${ }^{1}$ Department of Obstetrics and Gynaecology, Katholieke Universiteit Leuven, Leuven, Belgium \\ ${ }^{2}$ Laboratorium voor Experimentele Geneeskunde en Endocrinologie, Katholieke Universiteit Leuven, Leuven, Belgium \\ ${ }^{3}$ Department of Clinical Pathology, Katholieke Universiteit Leuven, Leuven, Belgium \\ (Requests for offprints should be addressed to J Verhaeghe, Department of Obstetrics and Gynaecology, U.Z. Gasthuisberg, Herestraat 49 , 3000 Leuven, \\ Belgium)
}

\begin{abstract}
1,25-Dihydroxyvitamin $\quad \mathrm{D}_{3} \quad\left(1,25(\mathrm{OH})_{2} \mathrm{D}_{3}\right)$ concentrations have been found to be decreased in diabetic humans and rats. To investigate further the regulation of plasma $\mathrm{Ca}$ in diabetes, first we measured $\mathrm{Ca}^{2+}, \mathrm{P}, \mathrm{Mg}$, parathyroid hormone ${ }_{1-34}(\mathrm{PTH})$, and total and free $1,25(\mathrm{OH})_{2} \mathrm{D}_{3}$ in male spontaneously diabetic rats 7 and 28 days after the onset of glycosuria. Secondly, we studied changes in the levels of PTH and $1,25(\mathrm{OH})_{2} \mathrm{D}_{3}$ in response to hypocalcaemia induced by an i.v. infusion of EGTA (2.5\%, wt/vol.) for $24 \mathrm{~h}$, and changes in the levels of $1,25(\mathrm{OH})_{2} \mathrm{D}_{3}$ in response to an i.v. infusion of rat PTH $(10 \mu \mathrm{g}$ over $24 \mathrm{~h})$ without or with concomitant EGTA infusion (producing hypercalcaemia or normo/ hypocalcaemia respectively), in diabetic and control rats.

$\mathrm{Ca}^{2+}, \mathrm{P}, \mathrm{Mg}$ and PTH concentrations remained within the control ranges after 7 and 28 days of glycosuria; $1,25(\mathrm{OH})_{2} \mathrm{D}_{3}$ concentrations were decreased after 7 , but not after 28, days of glycosuria. PTH concentrations showed a similar rise during EGTA-induced hypocalcae-
\end{abstract}

mia in control and diabetic rats compared with salineinfused rats, whereas $1,25(\mathrm{OH})_{2} \mathrm{D}_{3}$ concentrations were unchanged in both groups. Total and free $1,25(\mathrm{OH})_{2} \mathrm{D}_{3}$ levels were comparably (about 3-fold) increased during PTH, but not during combined PTH and EGTA infusion in control and diabetic rats. Total $1,25(\mathrm{OH})_{2} \mathrm{D}_{3}$ concentrations were lower in the diabetic groups infused with saline or PTH than in their respective controls, and there was a similar trend in the PTH+EGTA-infused group; free $1,25(\mathrm{OH})_{2} \mathrm{D}_{3}$ levels, however, were normal or increased in the diabetic groups, confirming our previous data.

The novel finding of this study is that, despite severe insulin deficiency and altered $1,25(\mathrm{OH})_{2} \mathrm{D}_{3}$ levels, the in vivo response of $\mathrm{PTH}$ levels to hypocalcaemia and the in vivo response of $1,25(\mathrm{OH})_{2} \mathrm{D}_{3}$ levels to $\mathrm{PTH}$ in diabetic rats are comparable with those found in nondiabetic rats. Journal of Endocrinology (1999) 162, 251-258

\section{Introduction}

There is a great deal of controversy about the effects of type 1 diabetes on circulating levels of calcium $(\mathrm{Ca})$, phosphate $(\mathrm{P})$, and the main calciotrophic hormones parathyroid hormone (PTH) and 1,25-dihydroxyvitamin $\mathrm{D}_{3}\left(1,25(\mathrm{OH})_{2} \mathrm{D}_{3}\right)$. In those studies in which ionised calcium $\left(\mathrm{Ca}^{2+}\right)$ was measured, a small but significant decrease has been documented in both diabetic children and adults (Fogh-Andersen et al. 1983, Saggese et al. 1988, Schwarz et al. 1992); this decrease persisted during a calcium infusion (Amado et al. 1987). Serum $\mathrm{P}$ concentrations were reported to be normal (Saggese et al. 1988, Schwarz et al. 1992), increased (Rødland et al. 1985) or decreased (Auwerx et al. 1988); intensifying the insulin therapy raised serum P levels (Raskin \& Pak 1981). PTH concentrations, measured by immunoassays that detect the intact hormone, were found to be within the normal range in diabetic adults (Schwarz et al. 1992, Gallacher et al. 1993), but a rise in PTH levels was noted after improvement of glycaemic control (Thalassinos et al. 1993); decreased levels of intact PTH were reported in diabetic children, with a sluggish response to a low-Ca diet (Saggese et al. 1988). Such 'functional hypoparathyroidism' has been attributed to hypomagnesaemia induced by increased $\mathrm{Mg}$ excretion (Saggese et al 1988). Yet, PTH concentrations increased normally during a citrateinduced hypocalcaemic clamp in diabetic adults (Schwarz et al. 1992). 1,25(OH $)_{2} \mathrm{D}_{3}$ concentrations were normal in insulin-treated diabetic adults (Storm et al. 1983, Nyomba et al. 1986, Auwerx et al. 1988, Gallacher et al. 1993); however, decreased levels of both total and free $1,25(\mathrm{OH})_{2} \mathrm{D}_{3}$ have been reported in diabetic children and adolescents (Frazer et al. 1981, Rødland et al. 1985, 
Saggese et al. 1988) during diabetic ketoacidosis - reversible after treatment (Storm et al. 1983), and in severely insulin-deficient adult diabetics in central Africa (Nyomba et al. 1986).

In severely insulin-deficient rats, i.e. untreated spontaneously diabetic BB rats or streptozotocin (SZ)-induced diabetic rats, blood $\mathrm{Ca}^{2+}$ was found to be normal in $\mathrm{BB}$ rats (Verhaeghe 1988). Serum PTH concentrations were reported to be increased (Schedl et al. 1978) or normal (Romero et al. 1995) after 9 days of SZ-induced diabetes, but suppressed after 25 (Romero et al. 1995) or 48 days (Hough et al. 1982) of SZ-induced diabetes. Decreased $1,25(\mathrm{OH})_{2} \mathrm{D}_{3}$ levels have been reported repeatedly in male SZ-induced diabetic rats (Schneider et al. 1977, Hough et al. 1982, Wilson et al. 1982, Nyomba et al. 1985, Romero et al. 1995) and in male spontaneously diabetic rats (Nyomba et al. 1989, Verhaeghe et al. 1990, 1993); interestingly, this is not the case in female nongravid spontaneously diabetic rats (Verhaeghe et al. 1988, 1989, 1994). Renal cortical slices from male diabetic rats produced less $1,25(\mathrm{OH})_{2} \mathrm{D}_{3}$ but more $24,25(\mathrm{OH})_{2} \mathrm{D}_{3}$ than control rats (Wongsurawat et al. 1983); however, kidneys are larger relative to body weight in diabetic rats (Pillion et al. 1988). We produced evidence that male diabetic rats have a higher metabolic clearance rate (MCR) of $1,25(\mathrm{OH})_{2} \mathrm{D}_{3}$ than control rats; in contrast, their calculated in vivo $1,25(\mathrm{OH})_{2} \mathrm{D}_{3}$ production rate per body weight remained within the control range (Verhaeghe et al. 1993).

In this study, we investigated (1) the longitudinal changes in $\mathrm{Ca}^{2+}, \mathrm{P}, \mathrm{PTH}$ and $1,25(\mathrm{OH})_{2} \mathrm{D}_{3}$ in male $\mathrm{BB}$ rats after 7 and 28 days of diabetes, (2) changes in the levels of PTH and $1,25(\mathrm{OH})_{2} \mathrm{D}_{3}$ in response to hypocalcaemia induced by an EGTA infusion for $24 \mathrm{~h}$, and (3) changes in the levels of $1,25(\mathrm{OH})_{2} \mathrm{D}_{3}$ in response to an infusion with PTH resulting in hypercalcaemia. The renal $1 \alpha-$ hydroxylase activity is generally considered to be regulated by four main factors: PTH (positive), $1,25(\mathrm{OH})_{2} \mathrm{D}_{3}$ itself, $\mathrm{P}_{\text {and }} \mathrm{Ca}^{2+}$ (negative) (Bell 1998). In addition, insulin was found to be a necessary co-factor for PTH to stimulate $1,25(\mathrm{OH})_{2} \mathrm{D}_{3}$ production in cultured chick kidney cells (Henry 1981). The ex vivo $1,25(\mathrm{OH})_{2} \mathrm{D}_{3}$ production by renal slices from diabetic rats was stimulated by PTH, but less so than in insulin-treated diabetic rats (Wongsurawat $\&$ Armbrecht 1985). To differentiate between the effects of $\mathrm{PTH}$ and $\mathrm{Ca}^{2+}$ on $1,25(\mathrm{OH})_{2} \mathrm{D}_{3}$ production (Bushinsky et al. 1985), both hypercalcaemic rats infused with PTH alone and normo- or hypocalcaemic rats infused with both PTH and EGTA were studied.

\section{Materials and Methods}

\section{Animals}

The experiments described below were approved by the Ethical Committee for Animal Research at Leuven
University. Male diabetic rats were obtained from the Leuven/pfd Wistar rat colony, inbred since 1983. Between 30 and $40 \%$ of these rats (38\% in 1997) develop spontaneous type 1-like diabetes at a mean age of 13 weeks. Diabetes was diagnosed by checking 5 times weekly for glycosuria, which invariably corresponds to a tail blood glucose level of $>300 \mathrm{mg} / \mathrm{dl}$. After onset of diabetes, the rats were untreated unless ketonuria was detected (checked 5 times weekly with KetoDiabur sticks from Boehringer, Mannheim, Germany), in which case 1 U Ultralente MC (Novo Nordisk, Bagsvaerd, Denmark) was administered s.c.; this regime leaves the diabetic rats untreated from a biological point of view, whilst preventing deaths due to ketosis. The rats were given tap water and a rat chow containing $0.94 \% \mathrm{Ca}, 0.62 \% \mathrm{P}, 0.18 \% \mathrm{Mg}$, and $1650 \mathrm{IU}$ vitamin $\mathrm{D}_{3} / \mathrm{kg}$ (Arie Blok, Woerden, The Netherlands) available ad libitum.

In Experiment 1, diabetic rats were studied 7 and 28 days after glycosuria was first detected; control rats were non-diabetic littermates. The rats were anaesthetized with pentobarbitone, $60 \mathrm{mg} / \mathrm{kg}$ intraperitoneally (i.p.), and a blood sample was drawn from the abdominal aorta. Ionised calcium was determined within 10 min after sampling; the sample was then centrifuged and plasma was stored at $-20{ }^{\circ} \mathrm{C}$.

In Experiment 2, diabetic rats with a diabetes duration between 2 and 4 weeks were used for infusion experiments; control rats were non-diabetic littermates. The rats were anaesthetized with atropine $0 \cdot 25 \mathrm{mg} / \mathrm{kg}$, xylazine hydrochloride $10 \mathrm{mg} / \mathrm{kg}$, and ketamine hydrochloride $50 \mathrm{mg} / \mathrm{kg}$ i.p. A catheter was inserted in the left jugular vein, and the rats were placed in a specially designed cage with the catheter connected to a swivel device that permitted sufficient movement of the rats within the cage to eat and drink ad libitum. For the first $24 \mathrm{~h}$, all rats received $0.9 \% \mathrm{NaCl}$. For the next $24 \mathrm{~h}$, the rats received either (1) $0.9 \% \mathrm{NaCl}$ (saline-infused group), (2) ethylene glycol-bis ( $\beta$-aminoethyl)-N,N,N $N^{\prime}, N^{\prime}$-tetraacetic acid (EGTA, Sigma Chemical Co., St Louis, MO, USA) $2 \cdot 5 \%$ (wt/vol.) in $0.9 \% \mathrm{NaCl}, \mathrm{pH} 7.4$ (EGTA-infused group), (3) rat PTH (Calbiochem, La Jolla, CA, USA) $10 \mu \mathrm{g} / 24 \mathrm{~h}$ dissolved in $0.9 \% \mathrm{NaCl}, \mathrm{pH} 7 \cdot 4$ (ratPTH-infused group), or (4) the combination of EGTA and rat PTH in the same concentrations as above (ratPTH+EGTA-infused group). EGTA was used and not EDTA, because of its lower affinity for $\mathrm{Mg}$ (Weisinger et al. 1989). All infusions were given with a model AS-6C Syringe Pump (Auto-Syringe Inc., Londonderry TPKE, Hooksett, NH, USA), and the infusion volume was $3 \mathrm{ml} / 24 \mathrm{~h}$ in all rats. After $24 \mathrm{~h}$, the rats were anaesthetized with pentobarbitone, and a blood sample was taken from the abdominal aorta, with the infusion still going.

For the rats to be included in Experiment 2 we proceeded as follows. Because we found in Experiment 1 that control as well as diabetic rats had $\mathrm{Ca}^{2+}$ levels between 1.16 and $1.33 \mathrm{mmol} / \mathrm{l}$, we defined the normocalcaemic 
Table 1 Body weight, blood ionised calcium and plasman values in male diabetic BB rats and their paired control littermates, $7(n=10)$ and $28(n=12)$ days after onset of glycosuria. Data are expressed as means (S.E.M.)

\begin{tabular}{|c|c|c|c|c|c|}
\hline & \multicolumn{2}{|l|}{7 Days } & \multicolumn{2}{|l|}{28 Days } & \multirow[b]{2}{*}{$\boldsymbol{P}$ value $(\mathrm{ANOVA})$} \\
\hline & Control & Diabetic & Control & Diabetic & \\
\hline Body weight (g) & $380(8)$ & $318(8)^{* \star}$ & $413(22)$ & $278(16)^{* *}$ & $<0.001$ \\
\hline Blood $\mathrm{Ca}^{2+}(\mathrm{mmol} / \mathrm{l})$ & $1 \cdot 26(0 \cdot 01)$ & $1 \cdot 25(0 \cdot 01)$ & $1 \cdot 25(0 \cdot 01)$ & $1 \cdot 24(0 \cdot 02)$ & $0 \cdot 64$ \\
\hline Plasma P (mmol/l) & $1 \cdot 83(0 \cdot 03)$ & $1 \cdot 87(0 \cdot 03)$ & $1 \cdot 82(0 \cdot 01)$ & $1 \cdot 89(0 \cdot 02)$ & 0.09 \\
\hline Plasma Mg (mmol/l) & $0 \cdot 71(0 \cdot 02)$ & $0.74(0 \cdot 02)$ & $0.68(0.02)$ & $0.74(0.03)$ & $0 \cdot 09$ \\
\hline Plasma glucose $(\mathrm{mmol} / \mathrm{l})$ & $10 \cdot 0(0 \cdot 3)$ & $27.9(0.9)^{* *}$ & $10 \cdot 6(0 \cdot 3)$ & $32 \cdot 0(1 \cdot 2)^{* *, \dagger}$ & $<0.001$ \\
\hline Plasma insulin (pmol/l) & $731(79)$ & $65(11)^{* \star}$ & $1083(201)$ & $84(21)^{* *}$ & $<0.001$ \\
\hline Plasma PTH (pmol/l) & $16 \cdot 0(2 \cdot 1)$ & $12 \cdot 0(1 \cdot 2)$ & $15 \cdot 4(2 \cdot 5)$ & $13 \cdot 0(2 \cdot 8)$ & $0 \cdot 60$ \\
\hline Plasma $1,25(\mathrm{OH})_{2} \mathrm{D}_{3}(\mathrm{pmol} / \mathrm{l})$ & $394(39)$ & $241(12)^{*}$ & $344(18)$ & $307(25)$ & $0 \cdot 001$ \\
\hline Plasma DBP $(\mu \mathrm{mol} / \mathrm{l})$ & $8 \cdot 2(0 \cdot 2)$ & $5 \cdot 1(0 \cdot 6)^{* *}$ & $8.5(0.3)$ & $5 \cdot 0(0 \cdot 2)^{* *}$ & $<0.001$ \\
\hline Plasma free $1,25(\mathrm{OH})_{2} \mathrm{D}_{3}$ (index) & $4 \cdot 8(0 \cdot 4)$ & $5 \cdot 3(0 \cdot 7)$ & $4 \cdot 1(0 \cdot 3)$ & $6 \cdot 2(0 \cdot 5)^{*}$ & $0 \cdot 02$ \\
\hline
\end{tabular}

${ }^{*} P<0 \cdot 01,{ }^{* *} P<0 \cdot 001$ vs respective control; $\nmid P<0 \cdot 05$ vs diabetic 7 days.

range for the purpose of this Experiment as being between 1.16 and $1.35 \mathrm{mmol} / 1(0.20 \mathrm{mmol} / 1$ range $)$. The target hypercalcaemic range for the rats infused with ratPTH was defined as a $\mathrm{Ca}^{2+}$ level between 1.36 and $1.60 \mathrm{mmol} / 1$ $(0.25 \mathrm{mmol} / 1$ range); the hypocalcaemic range for the rats infused with EGTA was defined as a $\mathrm{Ca}^{2+}$ level between 0.91 and $1.15 \mathrm{mmol} / 1(0.25 \mathrm{mmol} / 1$ range $)$. The response in the group infused with both EGTA and PTH was predictably variable, and all rats with a $\mathrm{Ca}^{2+}$ of $1.35 \mathrm{mmol} / 1$ or less (i.e. either normocalcaemic or hypocalcaemic) were included. Only those rats having the target $\mathrm{Ca}^{2+}$ values as defined entered the study, and their plasma was stored at $-20{ }^{\circ} \mathrm{C}$ for further analysis. Three control and six diabetic PTH-infused, as well as six control and five diabetic PTH+EGTA-infused rats were thus excluded.

\section{Assays}

Blood $\mathrm{Ca}^{2+}$ was measured by the ion selective electrode method on the Ciba Corning Z88 Blood Gas System (Chiron Diagnostics, Zaventem, Belgium). Plasma P was measured by colorimetry with ammonium molybdate (Daly \& Ertingshausen 1972), and Mg was measured by colorimetry with xylidylblue on the BM/Hitachi AutoAnalyzer (Boehringer). Plasma glucose was measured by the glucose-oxidase method with a YSI 2300 Stat Plus glucometer (Yellow Springs, OH, USA). Insulin was measured by radioimmunoassay using a rat insulin standard (Verhaeghe et al. 1986). PTH was measured by an immunoradiometric assay kit that is directed against the amino-terminal region (1-34) of the rat PTH molecule (Immunotopics, San Clemente, CA, USA). The sensitivity of this assay is $1 \mathrm{pg} / \mathrm{ml}(0 \cdot 25 \mathrm{pmol} / \mathrm{l})$, and the intra- and interassay coefficients of variation are $\leq 4 \cdot 7 \%$; this assay has been validated in vivo in rats injected with calcium chloride and EDTA (Rucinski et al. 1995). 1,25(OH) ${ }_{2} \mathrm{D}_{3}$ was measured by radioimmunoassay after HPLC purification (Bouillon et al. 1980); one of us (I J) has performed this assay since its description. The purification procedure we have used in this study was identical as described ibidem, but we have used an equilibrium assay rather than a non-equilibrium assay, with improved sensitivity: the specific activity of the radiolabelled $1,25(\mathrm{OH})_{2}\left({ }^{3} \mathrm{H}\right) \mathrm{D}_{3}$ was $180 \mathrm{Ci} / \mathrm{mmol}$, and the antiserum was diluted at $1: 100000$. As a result, less plasma is needed $(0.5-0.75 \mathrm{ml}$ in general). The detection limit is around $18 \mathrm{pg}$ per $1 \mathrm{ml}$ sample. The vitamin D-binding protein (DBP) was measured by single radial immunodiffusion (Bouillon et al. 1978); the 'free $1,25(\mathrm{OH})_{2} \mathrm{D}_{3}$ index' was calculated as the molar $1,25(\mathrm{OH})_{2} \mathrm{D}_{3} / \mathrm{DBP}$ ratio $\times 10^{5}$.

\section{Statistical analysis}

A software program (NCSS, Kaysville, UT, USA) was used. For Experiments 1 and 2, the overall differences were examined by one-way ANOVA; if $P<0.05$, Scheffe's post hoc test was used to detect significant $(P<0 \cdot 05)$ differences between groups. Unpaired $t$-tests were then used to quantify the level of significance between these groups.

\section{Results}

Seven days after onset of glycosuria, spontaneously diabetic BB rats weighed $84 \%$ of their nondiabetic littermates, and were severely hyperglycaemic and hypo-insulinaemic; 28 days after onset of glycosuria, body weight was $67 \%$ of controls, and the diabetic rats were slightly more hyperglycaemic than diabetic rats at 7 days (Table 1). There were no significant differences in blood $\mathrm{Ca}^{2+}$ or plasma $\mathrm{P}$ and $\mathrm{Mg}$ levels, nor in plasma PTH concentrations. DBP 
Table 2 Body weight and plasma values in infused BB rats. Data are expressed as means (S.E.M.)

\begin{tabular}{|c|c|c|c|c|c|c|c|c|}
\hline & \multicolumn{2}{|l|}{ Saline } & \multicolumn{2}{|l|}{ EGTA } & \multicolumn{2}{|l|}{ RatPTH } & \multicolumn{2}{|c|}{ RatPTH+EGTA } \\
\hline & Control & Diabetic & Control & Diabetic & Control & Diabetic & Control & Diabetic \\
\hline Body weight (g) & $368(21)$ & $264(16)^{*}$ & $382(14)$ & $271(13)^{* *}$ & $358(18)$ & $266(17)^{*}$ & $386(15)$ & $264(9)^{* *}$ \\
\hline Plasma insulin (pmol/l) & $851(116)$ & $46(12)^{* *}$ & $861(203)$ & $42(13)^{* *}$ & $655(91)$ & $45(10)^{* *}$ & $630(86)$ & $25(9)^{* *}$ \\
\hline Plasma DBP $(\mu \mathrm{mol} / \mathrm{l})$ & $9 \cdot 2(0 \cdot 3)$ & $5 \cdot 1(0 \cdot 4)^{* *}$ & $9 \cdot 2(0 \cdot 3)$ & $6 \cdot 1(0 \cdot 5)^{* *}$ & $8.7(0.4)$ & $5 \cdot 1(0 \cdot 3)^{* *}$ & $9 \cdot 0(0 \cdot 2)$ & $5 \cdot 4(0 \cdot 6)^{* *}$ \\
\hline Plasma Mg (mmol/l) & $0.59(0.02)$ & $0.64(0.04)$ & $0.62(0.02)$ & $0.57(0.02)$ & $0.69(0.02)^{\dagger}$ & $0.69(0.03)$ & $0.75(0.04)^{\dagger}$ & $0.71(0.04)$ \\
\hline
\end{tabular}

Because there were no significant differences in the results of the normo- and hypocalcaemic ratPTH+EGTA-infused rats (see Fig. 1 ), the results of the 2 subgroups were combined. ${ }^{*} P<0 \cdot 01,{ }^{*} P<0 \cdot 001$ vs respective control; $+P<0 \cdot 01$ vs saline control; $\$ P<0 \cdot 01$ vs saline diabetic and ratPTH+EGTA diabetic.

concentrations were 63 and $59 \%$ of the respective control levels in diabetic rats after 7 and 28 days of glycosuria respectively. Total $1,25(\mathrm{OH})_{2} \mathrm{D}_{3}$ concentrations were lower after 7 , but not after 28, days of glycosuria. Consequently, the $1,25(\mathrm{OH})_{2} \mathrm{D}_{3} / \mathrm{DBP}$ molar ratio was normal after 7 days of glycosuria, but was slightly increased after 28 days of glycosuria.

In the infusion experiments, the diabetic groups had body weights that were significantly lower than in the respective control groups, and all diabetic groups were severely hyperglycaemic and hypo-insulinaemic; the plasma glucose level was slightly higher in the diabetic group infused with EGTA than in the diabetic groups infused with either saline or ratPTH+EGTA (Table 2). Plasma DBP levels were uniformly decreased in all diabetic groups (between 55 and $66 \%$ of the respective control values).
Blood $\mathrm{Ca}^{2+}$ levels are depicted in Fig. 1: all rats infused with EGTA had $\mathrm{Ca}^{2+}$ levels between 0.98 and $1.11 \mathrm{mmol} / 1$; the rats infused with $\mathrm{PTH}$ had $\mathrm{Ca}^{2+}$ levels between 1.39 and $1.60 \mathrm{mmol} / \mathrm{l}$; in the rats infused with PTH and EGTA, $\mathrm{Ca}^{2+}$ levels were between $1 \cdot 17$ and $1.34 \mathrm{mmol} / 1$ (normocalcaemic group) or between 0.83 and $1 \cdot 12 \mathrm{mmol} / 1$ (hypocalcaemic group).

In the rats infused with EGTA and PTH, there was no significant difference in any parameter (weight, glucose, insulin, DBP, P, PTH, total and free $\left.1,25(\mathrm{OH})_{2} \mathrm{D}_{3}\right)$ other than the $\mathrm{Ca}^{2+}$ level between the normocalcaemic and hypocalcaemic subgroups, both in control and diabetic rats (unpaired $t$-tests, data not shown). Consequently, the results of both subgroups were combined in the subsequent analyses. The only significant difference was that $\mathrm{Mg}$ levels were lower $(P=0 \cdot 02)$ in hypocalcaemic $(1.61(0 \cdot 11))$ compared with normocalcaemic

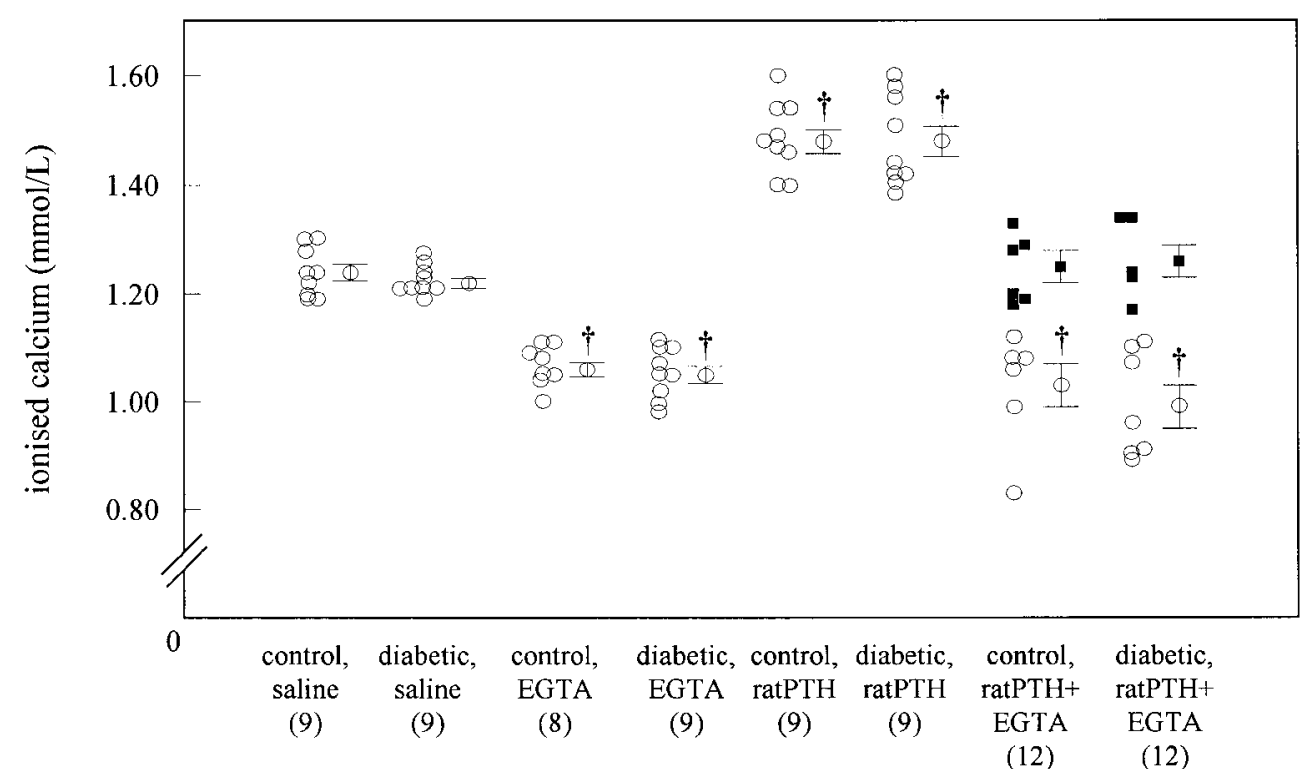

Figure 1 Individual blood $\mathrm{Ca}^{2+}$ levels and means \pm S.E.M. in the infused BB rat groups. Numbers of animals in each group are shown in parentheses. In the ratPTH+EGTA groups, hypocalcaemic $(\bigcirc)$ and normocalcaemic ( $\mathbf{\square})$ subgroups were defined. $+P<0 \cdot 001$ compared with respective saline-infused control/diabetic group. 

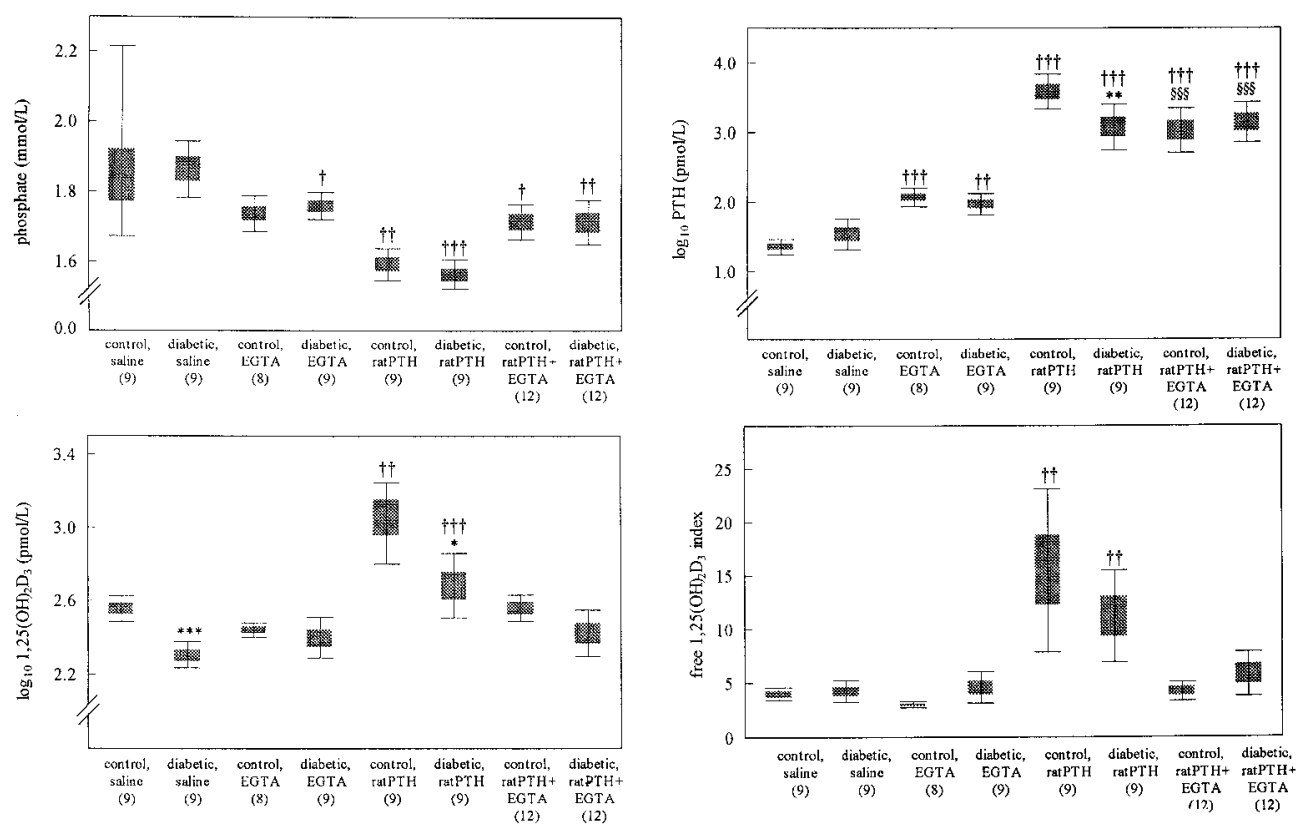

Figure 2 Box plots of the plasma levels of phosphate (left upper panel), $\log _{10}$ PTH (right upper panel), $\log _{10}$ $1,25(\mathrm{OH})_{2} \mathrm{D}_{3}$ (left lower panel) and free $1,25(\mathrm{OH})_{2} \mathrm{D}_{3}$ (right lower panel) in the infused BB rat groups. Because there were no significant differences in the results of normo- and hypocalcaemic ratPTH+EGTAinfused subgroups (see Fig. 1), the results of the 2 subgroups were combined. Numbers of animals in each group are shown in parentheses. ${ }^{\star} P<0 \cdot 05,{ }^{* *} P<0 \cdot 01,{ }^{* *} P<0 \cdot 001$ compared with respective control group; $+P<0 \cdot 05,+\dagger P<0 \cdot 01,+\dagger+P<0 \cdot 001$ compared with respective saline-infused control/diabetic group; $\S \S \S P<0 \cdot 001$ compared with respective EGTA-infused control/diabetic group.

$(2 \cdot 04(0 \cdot 11))$ control rats infused with PTH and EGTA; in diabetic rats, there was no significant difference $(P=0 \cdot 44)$.

The P levels were decreased by the EGTA infusion and by the PTH infusion compared with saline-infused rats, in both control and diabetic rats (although this was not significant in the control EGTA-infused group); the effects of EGTA and PTH infusion were not additive, however (Fig. 2). Plasma Mg levels were higher in control rats infused with PTH or PTH+EGTA (i.e. only the normocalcaemic subgroup) than in saline-infused control rats; there were no significant differences in plasma $\mathrm{Mg}$ in the diabetic groups versus the control groups, nor in the PTH-infused diabetic groups versus the saline-infused diabetic group (Table 2).

Because of the large variations in the individual $\mathrm{PTH}$ and $1,25(\mathrm{OH})_{2} \mathrm{D}_{3}$ concentrations (particularly in the PTH-infused groups), log corrections were used for statistical analysis and data presentation (Fig. 2). $\log _{10}$ PTH concentrations were increased in EGTA-infused control and diabetic groups compared with their respective saline-infused groups. As expected, the $\log _{10}$ PTH concentrations were even higher in the control and diabetic PTH-infused groups; the $\log _{10}$ PTH concentrations were lower in the diabetic PTH-infused group than in the control PTH-infused group, but there was no difference between the control and diabetic PTH+EGTA-infused groups. $\log _{10} 1,25(\mathrm{OH})_{2} \mathrm{D}_{3}$ concentrations were increased in the PTH-infused control and diabetic groups compared with their respective saline-infused groups (mean values were increased $3 \cdot 4$-fold in the control group and 2.6-fold in the diabetic group), but not in the PTH+EGTA-infused groups. $\log _{10} 1,25(\mathrm{OH})_{2} \mathrm{D}_{3}$ concentrations were lower in the saline- and PTH-infused diabetic groups than in the respective control groups, and there was a similar trend in the PTH+EGTA-infused diabetic group compared with the respective control group $(P=0 \cdot 06)$. The molar $1,25(\mathrm{OH})_{2} \mathrm{D}_{3} / \mathrm{DBP}$ index was increased in the PTH-infused control and diabetic groups compared with their respective saline-infused groups, but again this was not observed in the PTH+EGTA-infused groups. There were no significant differences in the free $1,25(\mathrm{OH})_{2} \mathrm{D}_{3}$ index between the control and diabetic groups. In a multiple regression analysis of the three independent variables $\left(\log _{10} \mathrm{PTH}\right.$, $\mathrm{P}$ and $\left.\mathrm{Ca}^{2+}\right)$ that predicted $\log _{10} 1,25(\mathrm{OH})_{2} \mathrm{D}_{3}$ concentrations (dependent variable), $\mathrm{Ca}^{2+}$ was a significant $(\mathrm{t}=5 \cdot 01, P<0 \cdot 001)$ predictive variable and $\mathrm{P}$ tended to be predictive $(\mathrm{t}=-1 \cdot 71, P=0 \cdot 097)$ in control rats; in diabetic rats, $P$ was the only significant predictive variable $(\mathrm{t}=-2 \cdot 41, P=0 \cdot 02)$. 


\section{Discussion}

This study demonstrates that there are no abnormalities in the plasma concentrations of $\mathrm{Ca}^{2+}, \mathrm{P}$ and $\mathrm{Mg}$, as well as $\mathrm{PTH}$, in male diabetic BB rats up to 4 weeks after the onset of diabetes, whereas total $1,25(\mathrm{OH})_{2} \mathrm{D}_{3}$ concentrations are generally lower in the diabetic groups. Furthermore, this study shows that hypocalcaemia, induced by an infusion with EGTA, results in a similar rise in PTH concentrations in diabetic and nondiabetic rats, and that an infusion with homologous $\mathrm{PTH}$ results in a comparable rise in total and free $1,25(\mathrm{OH})_{2} \mathrm{D}_{3}$ levels in diabetic and nondiabetic rats. These results indicate that severe insulin deficiency does not hamper the in vivo parathyroid response to a decrement in the $\mathrm{Ca}^{2+}$ level, nor the renal $1 \alpha$-hydroxylase activity response to PTH. Previous data reported by Wilson et al. (1982) and by some of us (Verhaeghe et al. 1988) have documented higher $1,25(\mathrm{OH})_{2} \mathrm{D}_{3}$ concentrations in diabetic rats with chronic dietary restriction of $\mathrm{Ca}$ and/or $\mathrm{P}$. We have also demonstrated a normal tissue-organ response to exogenous $1,25(\mathrm{OH})_{2} \mathrm{D}_{3}$ in diabetic rats, i.e. the mucosal-serosal $\mathrm{Ca}$ transport and concentrations of calbindin- $\mathrm{D}_{9 \mathrm{~K}}$ in the duodenum, and urinary $\mathrm{Ca}$ excretion and concentrations of calbindin- $\mathrm{D}_{28 \mathrm{~K}}$ in the kidneys (Verhaeghe et al. 1993). Hence, plasma Ca regulatory mechanisms - the negative feedback by $\mathrm{Ca}^{2+}$ on PTH concentrations, the stimulation of $1,25(\mathrm{OH})_{2} \mathrm{D}_{3}$ concentrations by $\mathrm{PTH}$, the stimulation of duodenal $\mathrm{Ca}$ absorption by $1,25(\mathrm{OH})_{2} \mathrm{D}_{3}-$ are functioning normally in vivo despite severe insulin deficiency. These data are in apparent disagreement with previous in vitro and ex vivo findings (Henry 1981, Wongsurawat \& Armbrecht 1985) that the renal $1 \alpha$-hydroxylase activity is insulin dependent. Further work should verify whether the down-regulation of PTH secretion by $1,25(\mathrm{OH})_{2} \mathrm{D}_{3}$ (Silver et al. 1986) is operative in insulin-deficient rats in vivo.

The plasma concentrations of total $1,25(\mathrm{OH})_{2} \mathrm{D}_{3}$ were decreased in some, but not all, diabetic groups in this study, i.e. in the saline- and ratPTH-infused diabetic groups of the infusion experiments, and in the diabetic group sampled after 7 days of glycosuria. However, normal levels were found in the EGTA-infused group, and in the diabetic group sampled after 28 days. We have no explanation for these discordant findings. In most studies that have used male diabetic rats, total $1,25(\mathrm{OH})_{2} \mathrm{D}_{3}$ concentrations were found to be lower than in the control group in SZ-induced diabetes (Schneider et al. 1977, Hough et al. 1982, Wilson et al. 1982, Nyomba et al. 1985, Romero et al. 1995) as well as in spontaneous diabetes (Nyomba et al. 1989, Verhaeghe et al. 1990, 1993). However, we have repeatedly found that $1,25(\mathrm{OH})_{2} \mathrm{D}_{3}$ concentrations in female nongravid diabetic $\mathrm{BB}$ rats remain within the control range, both in rats fed a standard diet and in rats fed a restricted Ca-P diet (Verhaeghe et al. 1988, 1989, 1994); in contrast, pregnant and lactating diabetic rats do have lower $1,25(\mathrm{OH})_{2} \mathrm{D}_{3}$ concentrations (Verhaeghe et al. 1986, 1988, 1989). Interestingly, both male and nongravid female diabetic rats exhibit lower active duodenal $\mathrm{Ca}$ absorption (assessed by the everted gut sac technique) and concentrations of calbindin- $\mathrm{D}_{9 \mathrm{~K}}$ in duodenal mucosa (Nyomba et al. 1989, Verhaeghe et al. $1990,1993,1994)$. We have previously documented that the MCR of $1,25(\mathrm{OH})_{2} \mathrm{D}_{3}$ is increased in male diabetic $\mathrm{BB}$ rats, and shows an inverse correlation with concentrations of DBP, the main plasma binding protein of the vitamin $\mathrm{D}$ metabolites. This is compatible with recent findings that the clearance of $25(\mathrm{OH}) \mathrm{D}_{3}$ is markedly accelerated in DBP-deficient transgenic mice (Safadi et al. 1999). Since male and female diabetic rats have comparably low levels of DBP, the sex difference in $1,25(\mathrm{OH})_{2} \mathrm{D}_{3}$ levels cannot be explained by differences in binding of $1,25(\mathrm{OH})_{2} \mathrm{D}_{3}$ to DBP. In addition, endogenous sex steroids appear to be unrelated to this observation, because there is no difference between plasma $1,25(\mathrm{OH})_{2} \mathrm{D}_{3}$ concentrations in ovariectomised diabetic and control rats, either untreated or treated with $17 \beta$-oestradiol (Verhaeghe et al. 1994, 1997). Further experiments should be designed to study the in vivo production and catabolism of $1,25(\mathrm{OH})_{2} \mathrm{D}_{3}$ in diabetic rats, and the regulation by sex-specific and environmental factors. In contrast to lower total $1,25(\mathrm{OH})_{2} \mathrm{D}_{3}$ concentrations, the free $1,25(\mathrm{OH})_{2} \mathrm{D}_{3}$ level either remains normal or is increased in male as well as in female diabetic rats (Nyomba et al. 1985, 1989, Verhaeghe et al. 1988, 1990, 1993, 1994). More specifically, we have found that the free $1,25(\mathrm{OH})_{2} \mathrm{D}_{3}$ index is normal or increased in male diabetic compared with control rats after short-term (6-10 days) (Table 1, Nyomba et al. 1985) and medium-term (2-4 weeks) diabetes (Table 1 and Fig. 2, Nyomba et al. 1989, Verhaeghe et al. 1993), and is normal after long-term (12 weeks) diabetes (Verhaeghe et al. 1990). Although the free $1,25(\mathrm{OH})_{2} \mathrm{D}_{3}$ concentration is generally considered to be the biologically active $1,25(\mathrm{OH})_{2} \mathrm{D}_{3}$ fraction, the discrepancy between normal/increased free $1,25(\mathrm{OH})_{2} \mathrm{D}_{3}$ and decreased duodenal $\mathrm{Ca}$ absorption in diabetic rats should be investigated further.

The infusion experiments with PTH and EGTA described here were modelled on the work of Bushinsky et al. (1985) and Weisinger et al. (1989), who presented data that $1,25(\mathrm{OH})_{2} \mathrm{D}_{3}$ concentrations correlate inversely with blood $\mathrm{Ca}^{2+}$ levels in chronically (24-h) infused rats. Further evidence that would support a negative regulation of $1,25(\mathrm{OH})_{2} \mathrm{D}_{3}$ levels by $\mathrm{Ca}^{2+}$ was produced by Fox (1992) in an elegant hypocalcaemic clamp experiment, and by Trechsel et al. (1980) who found higher $1,25(\mathrm{OH})_{2} \mathrm{D}_{3}$ concentrations in parathyroidectomised (PTX) rats fed a low versus normal $\mathrm{Ca}$-containing diet. The present study, however, shows that $1,25(\mathrm{OH})_{2} \mathrm{D}_{3}$ concentrations were up-regulated in the ratPTH-infused groups, which also demonstrated higher $\mathrm{Ca}^{2+}$ but lower $\mathrm{P}$ levels. In contrast, total and free $1,25(\mathrm{OH})_{2} \mathrm{D}_{3}$ 
concentrations were not up-regulated in the ratPTH+ EGTA-infused group with similar P and PTH but lower $\mathrm{Ca}^{2+}$ levels, which suggests either PTH resistance in the proximal tubules of the kidneys or increased $1,25(\mathrm{OH})_{2} \mathrm{D}_{3}$ catabolism in the latter group. Future studies should, therefore, measure the renal $1 \alpha$ - and $24 R$-hydroxylase activities in these rats. The differences between previously published results and our observations, based on a comparable experimental protocol, are difficult to explain. Factors that need to be taken into account include: the use of a radioligand versus radioreceptor assay for $1,25(\mathrm{OH})_{2} \mathrm{D}_{3}$; we only used parathyroid-intact rats; we used homologous PTH for all infusions. In addition, inconsistencies in some of the published data need further clarification. For example, mean serum $1,25(\mathrm{OH})_{2} \mathrm{D}_{3}$ concentrations varied 22-fold within a narrow $0.23 \mathrm{mmol} / 1 \mathrm{Ca}^{2+}$ range produced by infusions with bovine (b) PTH or EGTA+bPTH in parathyroid-intact rats (Bushinsky et al. 1985), but varied only 9-fold within a wider $0.53 \mathrm{mmol} / 1 \mathrm{Ca}^{2+}$ range produced by calcium chloride $\left(\mathrm{CaCl}_{2}\right)$ or EGTA infusions in ratPTH-treated PTX rats. Matsumoto et al. (1987) also reported alterations in $1,25(\mathrm{OH})_{2} \mathrm{D}_{3}$ levels that correlated negatively with variations in the $\mathrm{Ca}^{2+}$ level produced by $\mathrm{CaCl}_{2}$ or EGTA infusions in bPTH-treated PTX rats; however, severely hypocalcaemic untreated PTX rats had markedly lower, not higher, $1,25(\mathrm{OH})_{2} \mathrm{D}_{3}$ levels than hypercalcaemic bPTH-treated PTX rats. Clearly, more data are warranted on the interactive effects of $\mathrm{PTH}, \mathrm{P}$ and $\mathrm{Ca}^{2+}$ on the production and catabolism of $1,25(\mathrm{OH})_{2} \mathrm{D}_{3}$ in vivo.

In conclusion, the novel finding of this study is that, despite severe insulin deficiency and altered levels of DBP and total $1,25(\mathrm{OH})_{2} \mathrm{D}_{3}$, PTH levels increase normally during EGTA-induced hypocalcaemia in diabetic rats, and that $1,25(\mathrm{OH})_{2} \mathrm{D}_{3}$ levels change comparably in diabetic and control rats in response to exogenous $\mathrm{PTH}$, alone or in combination with EGTA.

\section{Acknowledgements}

This work was supported by grants from the Belgian Nationaal Fonds voor Wetenschappelijk Onderzoek (3.0157.95 and G.3C06.93 for Fundamental Clinical Research, both to J V). R B is supported by the J Servier Chair of Diabetes Research. Boehringer, Mannheim, Germany, and Novo Nordisk, Bagsvaerd, Denmark generously provided material for glucose control of the $\mathrm{BB}$ rats.

\section{References}

Amado JA, Gomez C, Obaya S, Otero M \& Gonzalez-Macias J 1987 Calcium and calcitonin responses to calcium infusion in type I diabetes mellitus. Postgraduate Medical Journal 63 249-252.
Auwerx J, Dequeker J, Bouillon R, Geusens P \& Nijs J 1988 Mineral metabolism and bone mass at peripheral and axial skeleton in diabetes mellitus. Diabetes 37 8-12.

Bell NH 1998 Clinical review. Renal and nonrenal 25hydroxyvitamin D-1 $\alpha$-hydroxylases and their clinical significance. Journal of Bone and Mineral Research 13 350-353.

Bouillon R, Vandoren G, Van Baelen H \& De Moor P 1978 Immunochemical measurement of the vitamin D-binding protein in rat serum. Endocrinology 102 1710-1715.

Bouillon R, De Moor P, Baggiolini EG \& Uskokovic MR 1980 A radioimmunoassay for 1,25-dihydroxycholecalciferol. Clinical Chemistry 26 562-567.

Bushinsky DA, Riera GS, Favus MJ \& Coe FL 1985 Evidence that blood ionized calcium can regulate serum $1,25(\mathrm{OH})_{2} \mathrm{D}_{3}$ independently of parathyroid hormone and phosphorus in the rat. Journal of Clinical Investigation 76 1599-1604.

Daly JA \& Ertingshausen G 1972 Direct method for determining inorganic phosphate in serum with the 'CentrifiChem'. Clinical Chemistry 18 263-265.

Fogh-Andersen N, McNair P, Moller-Petersen J \& Madsbad S 1983 Lowered serum ionized calcium in insulin treated diabetic subjects. Scandinavian Journal of Clinical and Laboratory Investigation 43 Suppl 165 93-97.

Fox J 1992 Hypocalcemia, but not PTH or hypophosphatemia, induces a rapid increase in $1,25(\mathrm{OH})_{2} \mathrm{D}_{3}$ levels in rats. American Journal of Physiology 262 E211-E215.

Frazer TE, White NH, Hough S, Santiago JV, McGee BR, Bryce G, Mallon J \& Avioli LV 1981 Alterations in circulating vitamin D metabolites in the young insulin-dependent diabetic. Journal of Clinical Endocrinology and Metabolism 53 1154-1159.

Gallacher SJ, Fenner JAK, Fisher BM, Quin JD, Fraser WD, Logue FC, Cowan RA, Boyle IT \& MacCuish AC 1993 An evaluation of bone density and turnover in premenopausal women with Type 1 diabetes mellitus. Diabetic Medicine 10 129-133.

Henry HL 1981 Insulin permits parathyroid hormone stimulation of 1,25-dihydroxyvitamin $\mathrm{D}_{3}$ production in cultured kidney cells. Endocrinology 108 733-735.

Hough S, Russell JE, Teitelbaum SL \& Avioli LV 1982 Calcium homeostasis in chronic streptozotocin-induced diabetes mellitus in the rat. American Journal of Physiology 242 E451-E456.

Matsumoto T, Ikeda K, Morita K, Fukumoto S, Takahashi H \& Ogata E 1987 Blood $\mathrm{Ca}^{2+}$ modulates responsiveness of renal $25(\mathrm{OH}) \mathrm{D}_{3}-1 \alpha$-hydroxylase to PTH in rats. American Journal of Physiology 253 E503-E507.

Nyomba BL, Bouillon R, Lissens W, Van Baelen H \& De Moor P 1985 1,25-Dihydroxyvitamin D and vitamin D-binding protein are both decreased in streptozotocin-diabetic rats. Endocrinology 116 2483-2488.

Nyomba BL, Bouillon R, Bidingija M, Kandjingu K \& De Moor P 1986 Vitamin D metabolites and their binding proteins in adult diabetic patients. Diabetes 35 911-915.

Nyomba BL, Verhaeghe J, Thomasset M, Lissens W \& Bouillon R 1989 Bone mineral homeostasis in spontaneously diabetic BB rats. I. Abnormal vitamin D metabolism and impaired active intestinal calcium absorption. Endocrinology 124 565-572.

Pillion DJ, Jenkins RL, Atchison JA, Stockard CR, Clements RS \& Grizzle WE 1988 Paradoxical organ-specific adaptations to streptozotocin diabetes mellitus in adult rats. American Journal of Physiology 254 E749-E755.

Raskin P \& Pak CYC 1981 The effect of chronic insulin therapy on phosphate metabolism in diabetes mellitus. Diabetologia 21 50-53.

Rødland O, Markestad T, Aksnes L \& Aarskog D 1985 Plasma concentrations of vitamin $\mathrm{D}$ metabolites during puberty of diabetic children. Diabetologia 28 663-666.

Romero DF, Bryer HP, Rucinski B, Isserow JA, Buchinsky FJ, Cvetkovic M, Liu CC \& Epstein S 1995 Amylin increases bone volume but cannot ameliorate diabetic osteopenia. Calcified Tissue International 56 54-61. 
Rucinski B, Mann GN \& Epstein S 1995 A new rapid and reproducible homologous immunoradiometric assay for amino-terminal parathyroid hormone in the rat. Calcified Tissue International 56 83-87.

Safadi FF, Thornton P, Magiera H, Hollis BW, Gentile M, Haddad JG, Liebhaber SA \& Cooke NE 1999 Osteopathy and resistance to vitamin $\mathrm{D}$ toxicity in mice null for vitamin $\mathrm{D}$ binding protein. Journal of Clinical Investigation 103 239-251.

Saggese G, Bertelloni S, Baroncelli GI, Federico G, Calisti L \& Fusaro C 1988 Bone demineralization and impaired mineral metabolism in insulin-dependent diabetes mellitus. A possible role for magnesium deficiency. Helvetica Paediatrica Acta 43 405-414.

Schedl HP, Heath H \& Wenger J 1978 Serum calcitonin and parathyroid hormone in experimental diabetes: effects of insulin treatment. Endocrinology 103 1368-1373.

Schneider LE, Schedl HP, McCain T \& Haussler MR 1977 Experimental diabetes reduces circulating 1,25-dihydroxyvitamin D in the rat. Science 196 1452-1454.

Schwarz P, Sørensen HA, Momsen G, Friis T, Transbøl I \& McNair P 1992 Hypocalcemia and parathyroid hormone responsiveness in diabetes mellitus: a tri-sodium-citrate clamp study. Acta Endocrinologica 126 260-263.

Silver J, Naveh-Many T, Mayer H, Schmelzer HJ \& Popovtzer MM 1986 Regulation by vitamin D metabolites of parathyroid hormone gene transcription in vivo in the rat. Journal of Clinical Investigation $\mathbf{7 8}$ 1296-1301.

Storm TL, Sørensen OH, Lund B, Lund B, Christiansen JS, Andersen AR, Lumholtz IB \& Parving H-H 1983 Vitamin D metabolism in insulin-dependent diabetes mellitus. Metabolic Bone Diseases and Related Research 5 107-110.

Thalassinos NC, Hadjiyanni P, Tzanela M, Alevizaki C \& Philokiprou D 1993 Calcium metabolism in diabetes mellitus: effect of improved blood glucose control. Diabetic Medicine 10 341-344.

Trechsel U, Eisman JA, Fischer JA, Bonjour J-P \& Fleisch H 1980 Calcium-dependent, parathyroid hormone-independent regulation of 1,25-dihydroxyvitamin D. American Journal of Physiology 239 E119-E124.

Verhaeghe J 1988 Calcium metabolism during reproduction in the diabetic BB rat. Thesis Katholieke Universiteit Leuven, p 59.

Verhaeghe J, Bouillon R, Nyomba BL, Lissens W \& Van Assche FA 1986 Vitamin D and bone mineral homeostasis during pregnancy in the diabetic BB rat. Endocrinology 118 1019-1025.
Verhaeghe J, Bouillon R, Lissens W, Visser WJ \& Van Assche FA 1988 Diabetes and low Ca-P diet have opposite effects on adult and fetal bone mineral metabolism. American Journal of Physiology 254 E496-E504.

Verhaeghe J, Van Herck E, Van Bree R, Van Assche FA \& Bouillon R 1989 Osteocalcin during the reproductive cycle in normal and diabetic rats. Journal of Endocrinology 120 143-151.

Verhaeghe J, Van Herck E, Visser WJ, Suiker AMH, Thomasset M, Einhorn TA, Faierman E \& Bouillon R 1990 Bone and mineral metabolism in $\mathrm{BB}$ rats with long-term diabetes. Decreased bone turnover and osteoporosis. Diabetes 39 477-482.

Verhaeghe J, Suiker AMH, Van Bree R, Van Herck E, Jans I, Visser WJ, Thomasset M, Allewaert K \& Bouillon R 1993 Increased clearance of $1,25(\mathrm{OH})_{2} \mathrm{D}_{3}$ and tissue-specific responsiveness to $1,25(\mathrm{OH})_{2} \mathrm{D}_{3}$ in diabetic rats. American Journal of Physiology 265 E215-E223.

Verhaeghe J, Suiker AMH, Einhorn TA, Geusens P, Visser WJ, Van Herck E, Van Bree R, Magitsky S \& Bouillon R 1994 Brittle bones in spontaneously diabetic female rats cannot be predicted by bone mineral measurements: studies in diabetic and ovariectomized rats. Journal of Bone and Mineral Research 9 1657-1667.

Verhaeghe J, Oloumi G, Van Herck E, van Bree R, Dequeker J, Einhorn TA \& Bouillon R 1997 Effects of long-term diabetes and/or high-dose $17 \beta$-estradiol on bone formation, bone mineral density, and strength in ovariectomized rats. Bone $20421-428$

Weisinger JR, Favus MJ, Langman CB \& Bushinsky DA 1989 Regulation of 1,25-dihydroxyvitamin $\mathrm{D}_{3}$ by calcium in the parathyroidectomized, parathyroid hormone replete rat. Journal of Bone and Mineral Research 4 929-935.

Wilson HD, Horst RL \& Schedl HP 1982 Calcium intake regulates 1,25-dihydroxyvitamin D formation in the diabetic rat. Diabetes 31 401-405.

Wongsurawat N \& Armbrecht HJ 1985 Insulin modulates the stimulation of renal 1,25-dihydroxyvitamin $\mathrm{D}_{3}$ production by parathyroid hormone. Acta Endocrinologica 109 243-248.

Wongsurawat N, Armbrecht HJ, Zenser TV, Davis BB, Thomas ML \& Forte LR 1983 1,25-Dihydroxyvitamin $\mathrm{D}_{3}$ and 24,25dihydroxyvitamin D3 production by isolated renal slices is modulated by diabetes and insulin in the rat. Diabetes 32 302-306.

Received 19 October 1998

Accepted 22 March 1999 